\title{
Hypermutated Colorectal Carcinoma
}

National Cancer Institute

\section{Source}

National Cancer Institute. Hypermutated Colorectal Carcinoma. NCI Thesaurus. Code C162256.

A colorectal carcinoma characterized by a high mutational rate caused by DNA mismatch repair deficiency or POLE/POLD1 driver mutations. 